\title{
Junior doctors' dispute leaves big questions about state of NHS
}

\author{
Time for acknowledgment of the deep malaise around medical training and honest public debate \\ on the problems with the health service
}

\author{
Neena Modi professor of neonatal medicine \\ Imperial College London, Chelsea and Westminster Hospital Campus, London SW10 9NH, UK
}

Last week, a High Court rejected arguments over the legality of the actions of the health secretary, Jeremy Hunt, in connection with a new contract for doctors in training. ${ }^{1}$ The claims, brought by five junior doctors in England through Justice for Health, a group resourced by public crowdfunding, were threefold: the health secretary had no lawful power to impose a contract; his decision was made in a manner so opaque and confused that it violated the principles of transparency and good administration; and his decision was irrational and based on inadequate evidence. $^{2}$

In a rather surprising turn of events, the action clarified that, in the words of counsel for the claimants, "Mr Hunt is not imposing a contract on junior doctors; he never was; he did not suggest he was; he never thought anyone thought otherwise." Mr Justice Green agreed that the health secretary's statement to parliament on 6 July 2016 did lead the junior doctors to conclude that he intended to "impose," but employers correctly "understood the statement as the minister intended it to be understood." Counsel for the claimants also noted: "This case is all about what happens when loose language is used and meanings [are] imperfectly conveyed and the very serious consequences which can flow from those words"

The consequences are indeed serious. The ruling was the latest twist in a long drawn out, damaging dispute that has brought thousands of young doctors onto the streets to protest. It was important in clarifying specifics, most notably establishing that employers are not legally compelled to adopt the proposed contract and that negotiations can continue. However, the impasse, the frustration, and the anger of junior doctors driven to industrial action for the first time in many decades remain unresolved. The total breakdown of trust between government and junior doctors represents a catastrophic failure of senior leadership at all levels. The important question is where this leaves patient care. During protests, junior doctors' placards carried multiple versions of the cry, "Save our NHS," with not a word about worker's rights, union demands, better conditions, or more pay.
Why does the NHS need saving? The first issue is that the NHS today, as Mr Justice Green stated, is "not a single body but a collection of different organisations, both public and private"; the second is that it is in disarray. Funding is at an all time low, services are being withdrawn, workforce numbers are inadequate, children and the most vulnerable are falling between the cracks; meanwhile, the pace of costly, untested reorganisation is extraordinary. It is a testament to the dedication of junior doctors and all other frontline healthcare staff that the public has been largely shielded from the consequences of this chaos; the corollary is that most people are unaware of the extent of the change the NHS is undergoing.

The junior doctors-not naive, ill informed striplings but an intelligent group of skilled clinicians with many years of training and experience- know the true state of the health services only too well; they work the longest hours delivering direct patient care, picking up the repercussions of cuts to clinical and administrative services and staff shortages. They are qualified practitioners called on to make life-and-death decisions in conditions often far from ideal; simultaneously, they are treated rather as children at school, obliged to tick boxes to show progression, document feedback on performance, demonstrate written evidence of reflection, and comply with burdensome bureaucracy. Their protest is both an expression of breaking point frustration with their training and a clarion call to the country to wake up and recognise the true state of the nation's health services.

So how to redress this dangerous tipping point? Firstly, there is an overriding need to re-establish trust, restore morale, and respect young doctors as the professionals that they are. This will not be easy and requires maturity, frank acknowledgment of mistakes, honesty of purpose, and a trusted space for dialogue and reconciliation. Secondly, the contract, regardless of any further tweaks, will forever be damaged goods, and in this same spirit of building trust should be discarded and replaced with one drawn on a clean sheet. Thirdly, patients and the public must be part of a conversation, conducted with integrity, about the nation's health services. The country is still reeling from 
the betrayal of honour in public service by the false assertion that $£ 350 \mathrm{~m}$ ( $€ 400 \mathrm{~m} ; \$ 450 \mathrm{~m}$ ) a week would be available to the NHS after the UK left the European Union. ${ }^{3}$

The questions are clear. Do we want healthcare that is efficient, effective, and equitable, delivered by a modern public sector organisation driven not by financial incentives but by pride in outcomes measured to rigorous standards? Do we consider health a commodity or an essential component of a just society, crucial to the economic wellbeing of the nation? The painful political awakening of a generation of young doctors may ultimately prove the catalyst to find a way forward.
Competing interests: I have read and understood BMJ policy on declaration of interests and declare that I am president of the UK Royal College of Paediatrics and Child Health.

Provenance and peer review: Commissioned; not externally peer reviewed.

1 Dyer C. Junior doctors lose legal challenge over contract imposition. BMJ 2016;354::5300. doi:10.1136/bmj.i5300 pmid:27682192.

2 Justice for Health. Judgment day: 28.09.2016. http://www.justiceforhealth.co.uk.

3 Griffin A. Brexit: Vote Leave wipes NHS £350m claim and rest of its website after EU referendum. Independent 2016 Jun 27. http://www.independent.co.uk/news/uk/homenews/brexit-vote-leave-wipes-nhs-350m-claim-and-rest-of-its-website-after-eu-referenduma7105546.html

Published by the BMJ Publishing Group Limited. For permission to use (where not already granted under a licence) please go to http://group.bmj.com/group/rights-licensing/ permissions 